\title{
Cash Benefits for Sickness and Maternity in Selected States of the European Union and Austerity Measures
}

\author{
PaedDr. Zuzana Horváthová, Ph. D. \\ Department of Law and Public Administration, Metropolitan University Prague \\ Email: zuzana. horvathova@mup.cz
}

Assoc. Prof. Ing. Josef Abrhám, Ph. D.

Department of Law and Public Administration, Metropolitan University Prague

Email: josef. abrham@mup.cz

Assoc. Prof. JUDr. Iva Chvátalová, CSc.

Department of Law and Public Administration, Metropolitan University Prague

Email: iva. chvatalova@mup.cz

\begin{abstract}
The paper introduces the results of the research focused on cash benefits for sickness and maternity in selected Member States of the European Union during the financial crisis and concerns the economic and demographic data. The aim was to determine whether and to what extent the expected austerity measures touched the monitored social area. For the paper we studied the situation from 2009 to 2014, especially in relation to employees and employers. Regarding the methods of the research, the authors gathered the data obtained from the relevant legal, statistical and other printed documents as well as the documents from the website of the European Union, relevant national ministries, social insurance companies, sickness funds and similar institutions. They undertook a legal, economic and demographic data analysis and consequently its comparisons as well as the final evaluation.
\end{abstract}

Keywords: social security, health insurance, maternity cash benefit, macroeconomic factors

\section{Introduction}

Owing to not only the financial crisis, the economic situation in the last few years made the Czech Republic adopt austerity social measures and the process continues even now. One of the sources of inspiration for their further formulation represents an analysis of legal regulations in some European Union countries. When making a choice, the authors took into account a standard breakdown of social policies, including social security proposed by G. Esping-Andersen (EspingAnderson, 1990), and chose prototypes of liberal, conservative, social democratic and South-European and Central and East-European models. They decided to include both the EU 15 countries as well as the states, which joined later, preferably the historically close Slovak Republic, and also those where the changes in the social area can be expected. They also took into account the financial situation of the countries which are receiving or eventually will receive financial assistance from the EU. Based on the above mentioned the authors examined the regulatory developments and economic and demographic indicators in the Czech Republic, Estonia, Finland, Ireland, Latvia, Germany, Austria, Greece, Slovak Republic, Spain and in Sweden.

The research focused in a greater detail on the legislation and other relevant documents that guided and guide the processes in the selected EU Member States concerning three major cash benefits for sickness insurance - sickness, 
maternity and nursing pays. In terms of time the research focused on the legal situation from 2009 up to 2014 . In the Czech Republic, the duties of employers to the employees that are unable to work have been discussed many times and we can expect further changes. Therefore, this aspect was put in the centre of the attention in the given countries, namely the obligation of employers to participate financially in the period of incapacity of employees, or during a maternity leave, respectively.

Decision making on austerity measures should be based on the assessment of many factors, not only purely the economic ones, but also of the evolution of demographic indicators, the development of incapacity for work, of the priorities of the state population policy, etc. On the basis of the economic and demographic data that illustrate the social security system, including changes in cash benefits sickness insurance, the authors focused on economic growth, convergence as well as on public finance and population development.

The aim of the study was both to assess the development of the legislation for sickness, maternity and nursing benefits in selected Member States of the European Union in the context of economic developments during the financial crisis as well as to verify whether and to what extent the expected austerity measures touched the monitored areas. The authors first formulated and subsequently verified the input hypotheses. In the case of sickness substantial interventions were expected in several parameters, in particular the benefit cuts, prolongation of the benefit or the introduction of the waiting period and strengthening the role of employers in addressing the situation of employees disable to work, respectively. For maternity benefit one expected keeping its status quo with regard to demographic developments in Europe, particularly related to population aging associated, besides others, with the decreasing birth rate. Changes in nursing pays were not expected, given the fact that this is usually paid for a limited period of time that is significantly shorter than the period of support for sickness and maternity pays. The impact of austerity measures would be marginal, then.

Regarding the methods of the research, the authors gathered the data obtained from the relevant legal, statistical and other printed documents as well as the documents from the website of the European Union, relevant national ministries, social insurance companies, sickness funds and similar institutions. They undertook a legal, economic and demographic data analysis and consequently its comparison and the final evaluation.

\section{Economic and demographic factors in the selected Member States of the European Union}

The financial, economic and subsequently the debt crisis caused significant changes in the development of key macroeconomic indicators. The traditionally estimated effects of the integration process have not shown in the recent years. Faster growth in less developed countries and their convergence to the EU average as a result of the trade and movement of capital between Member States has stopped. In recent the years, on the contrary, we have been witnessing a favourable growth in the core countries of the North West Europe compared to the countries of the called South Wing. The common currency is currently contributing to the divergence in the euro area membership, which is contrary to the original intentions of the project of the common currency. Out of the countries analysed in the given period the above-average growth rate in EU showed Germany, Sweden and partly also Austria. A group of trouble countries represented, out of the examined countries, namely Greece, Spain, but also Ireland. The gross domestic product of Greece declined even in all of the monitored years (2009-2014) and the economic level of the country fell from 92\% in 2008 to $72 \%$ of the average EU_27 in 2014 (EUROSTAT Database). In the case of Ireland and Spain, the decline in gross domestic product was slower, which can be derived from the divergent course of the debt crisis. The main cause of the crisis in Greece was a long undisciplined fiscal policy (a bloated public sector), combined with the loss of external competitiveness of the economy. The share of public debt to gross domestic product in the period of entry into the Eurozone was already higher than $100 \%$ limit of and continued to increase to $150 \%$ (EUROSTAT Database). Before the start of the mortgage crisis Ireland belonged among the economies with relatively low public debt. The main reason for the sharp deterioration in public finances and debt was the rehabilitation of the affected banking sector by the state. In the case of Spain, the reason was a combination of the mortgage crisis and problems with external competitiveness. The economic growth combined with low interest rates led to a rapid credit growth in the Spanish real estate market. The rapid growth in property prices stimulated the domestic consumption, wages grew faster than labour productivity and a relative competitiveness deteriorated (Bures, 2012). Unlike Greece, Spain showed balanced public finances before the onset of the debt crisis. 
It can be concluded that the main factor of the success during a recession became the stability of the economies. A common feature of the Eurozone economies in trouble is so called double deficit, which includes both public finance deficit and the deficit of the current account of the balance of payments. The double deficits are evident in Greece, Spain and Ireland. Conversely, developed countries of the North West Europe achieve a surplus in foreign trade. In the case of Germany, the share of the balance of the current account relative to GDP makes more than $5 \%$ in the long term, while in Sweden and the Netherlands the share is even higher. Developed economies of the Eurozone reached, in EU comparison, above the average growth rate of their gross domestic product. Mostly it was also confirmed that the impact of the economic recession in the short term was not so pronounced in countries with well-developed social model.

Shall we examine the causes of the loss of competitiveness of the south-Europe economies and vice versa the increase in export performance of Germany, we find that the cause was a different development of the price levels. The price level in Germany and other developed countries grew slower after the adoption of the common currency than in less developed countries, causing a gradual loss of the competitiveness. Nowadays it is already indisputable that the mere correction of public finances is not a sufficient solution to the countries affected by the crisis. The problem of external competitiveness can be assessed as even a more serious one. The affected states should seek mechanisms to correct the state of the current account deficit, but that is difficult when it is impossible to weaken the exchange rates of these countries. Within the euro area there may be used only structural measures to improve the competitiveness of exports, and also measures to restrict the domestic consumption. Strictly speaking, these are reductions of wages and prices in the domestic economy. In case of remaining with the Eurozone, the peripheral economies will be therefore forced to continue to operate in an environment of declining consumption, economic levels and growing unemployment. Simply we can say that the current exchange rate of the Euro is too strong for the South-European economies and relatively favourable for the stable countries of the North West Europe.

In analysing the new Member States of Central and Eastern Europe (we examine the Czech Republic, Slovakia, Estonia and Latvia) one may, according to the impacts of the economic crisis, identify two distinct groups of countries. First, there is Central Europe, which passed the recession, but the impact on the economic dynamics was average in the comparison to the European Union. By contrast, the Baltic States are examples of the economies that were affected very significantly. However, the imbalances were reduced relatively quickly due to appropriately applied economic policies. A typical example of such a development in the framework of the Baltic countries is Latvia, where due to the enormously strong GDP growth in the second half of the past decade the economy got overheated and there was a build-up of macroeconomic imbalances that were manifested in the excess of the domestic demand, double-digit inflation rate, the faster growth in labour costs than in productivity as well as in the deficit of the current account. Subsequently, there was a contribution of the overheated real estate market and the banking sector crisis. The government and the central bank responded to the emergency situation with a set of fairly strong measures, which aimed to restore the balance by restoring the competitiveness. The devaluation of the exchange rate was rejected because of the negative impacts on the economy. The central bank primarily pointed at the risk of the price increase of the imports, at weakening of the banking sector and a reduced motivation of the businesses to solve the problem of declining productivity (Rimševičs, 2012:7). Thus other measures in the areas of fiscal and structural policies were implemented. Namely, there was a significant reduction of budgetary spending. The number of employees of public sector and their wages were cut down. There was also a decrease in investments in health and social policy and the pension system was revised (Rimševičs, 2012:7). The reforms resulted in strong negative impacts on the economic and social levels of the population (a decline in average incomes and high growth of unemployment), but also in a relatively rapid restoration of the equilibrium and accelerating the economic growth. After a period of a sharp decline between 2009 and 2010 the Baltic States have recorded the fastest growth within the European Union since 2011. Additionally in 2013 Latvia managed to fulfil the convergence criteria and even joined the Eurozone. Estonia has not undergone such a significant crisis as Latvia, but also experienced a decline in economic growth and a significant increase in the unemployment. Estonia's economic imbalance and the subsequent recession, however, allowed for an accession to single currency, which had been impossible during the economic boom of the past decade because of the inability to meet the convergence criterion set for the inflation (European Central Bank, 2010).

Despite the fact that public finances are not the only problem of the current debt crisis, they represent, for most European countries, a key challenge for keeping a balanced economic development in the next decade. The biggest public budget deficits in recent years showed South-Europen states, Ireland and Latvia. Enormous deficits in Ireland in 2009 and 2010 but were caused, as mentioned above, by the crisis in the banking sector and hence cannot be combined with a lack of the fiscal discipline. The time-limited episode in Latvia was caused by the economic downturn rather than by the 
mismanagement. In Germany, Austria, the Czech and Slovak Republics there may be seen a substantial deterioration, but with the exception of Slovakia it does not go above average in the comparative profile of the European Union (compare with the average of the EU_27). In contrast, almost a smooth evolution can be observed in the case of Sweden and Estonia, which have also a low public debt. When comparing the success of individual typologies of social models, we can derive a definite relationship between fiscal discipline and the South-European social model. Other associations are not seen as among the countries with low public debt within the monitored group there were included both liberal (Estonia) and pretty much socially conceived states such as Sweden (European Commission, 2013: 5).

Perhaps no EU Member State could avoid taking austerity measures of varying intensity during the economic recession. The significance of fiscal interventions differed according to the economic and political environments in the countries concerned. One cannot find a direct correlation between the amount of public budget deficits and the depth of the austerity measures. The explanation can be found in a number of interconnections. Reducing public spending could exert pressures on the part of residents and voters, so politicians are trying to avoid that. It can also happen that the austerity measures impede the economic growth. Another question is what parts of the budget the imposed austerity measures affect. Having a specific look at the development of social protection expenditures, we believe that in the period 2009-2013 the expenses of Germany, Greece, Estonia and Latvia fell significantly. Other states preferred savings in other expenditure items.

The following text will focus on the development of the demographic indicators as other possible factors in spending on social protection. Even in this respect the group of the countries surveyed does not constitute a homogenous unit. Ireland and Sweden are among the countries with the highest total fertility rate in the European Union. In both countries, the fertility rate is of around 2 points. Other states are among the countries with a population below the average total fertility rate set between 1.3 and 1.5 points. The total fertility rate reflects very well on long-term population development, however, shortterm trends can be accurately assessed on the number of births each year. When looking at the period 2009-2013 in the context of the last ten years, it can be stated that the Scandinavian countries culminated in the current baby boom in 2010 (the largest number of live births since 2000), the Slovak Republic and Ireland in 2009, the Czech Republic, the Baltic States and South-European countries in 2008. Only Germany and Austria showed the largest increases significantly earlier (around the year 2004). We can then tend to the conclusion that holding the current level of maternity pay or even prolonging their receipt in the period in most countries surveyed has real demographic causes (EUROSTAT Database).

\section{Changes in sickness, maternity and nursing in the examined countries of the European Union}

The research showed that the substantial austerity measures were adopted in the Czech Republic, Estonia, Ireland and Latvia. Certain changes occurred in Greece and Slovakia. Changes leading to the austerity measures were not recorded in Finland, Germany, Austria, Sweden and Spain.

Based on the analysis, comparison and the subsequent assessment of all the data collected, it was possible to verify the input hypothesis, according to which, and given the financial crisis, the austerity measures in the social sphere will also affect the monitored sickness cash benefits.

The first hypothesis is related to sickness. The assumption was that substantial interventions will affect multiple parameters, especially the extension of the reduction of the benefit or the introduction of the waiting period and strengthening the role of employers in addressing the situation of employees disable to work, respectively.

This hypothesis was confirmed mainly in the countries that joined the EU in 2004 and in Ireland and Greece.

In Greece, there was a partial amendment concerning the tightening of conditions for the waiting period, i. e. the required length of insurance, which is one of the conditions for the disability pay. Of the original 110 days (for construction workers it was 90 days) the spell was extended to 120 days (for construction workers it makes 100 days).

The change in the amount of sickness pays occurred in several states. In Estonia, the standard rate of sickness benefit was reduced as part of the austerity measures in the economy, from the original $80 \%$ to $70 \%$ of the set income. In Ireland, where the benefit is paid at a flat rate, the amount gradually decreased taking into account the income level. For sake of completeness, it should be noted that sickness benefit in Ireland further increases a lump sum taking into account the number of dependent adults and children. For example, the maximum amount of sickness pay accounted for 204. 30 Euro per week in 2009 (European Commission, 2009), but only 188 Euro per week in 2011; between 2012 and 2014 the benefit 
remained the same. In Latvia, for a transitional period of 2010 to 2014, it was determined that half of the amount above 16 Euro per day belongs to the state budget. Originally, the reduction was established only for the year 2012, but it was extended as an anti-crisis measure. In the Czech Republic the sick pay was reduced down to $60 \%$ (European Commission, 2013). As a rule, until the 30th calendar day of illness $60 \%$ of the daily assessment base belonged to the hospital; from the 31 st to the 60 th calendar day of a temporary incapacity the daily assessment base made $66 \%$ and from the 61 st calendar day the daily assessment base made $72 \%$. The adopted measure was initially deemed applicable for 2010 and its aim was to reduce the budget deficit (European Commission, 2014).

The prolongation of the waiting period occurred in Estonia and from one day to three days, and in Ireland where it changed from three days to six ones. In the Czech Republic and the Slovak Republic the withdrawal period was significantly reduced. In both countries the period was adjusted identically from 42 calendar days to 7 calendar days (European Commission, 2010).

Shortening the period of support for sickness benefit was not expected and occurred only in Latvia (European Commission, 2009). The period of support was during 2009 reduced from 52 weeks to 26 weeks in case of the incapacity for work (except for special exceptions), and from 78 weeks to 52 weeks in case of repeated sick leaves falling within the period of three years.

Regarding the status of the employer, this changed in the reporting period in the Czech Republic and Estonia. In the Czech Republic, the Labour Code, as amended 1. 1. 2009 to 31. 12. 2010 anchored the obligation of employers to pay, during the period from the 4th day to the 14th day of sick leave, a wage compensation. Only in the year 2011 the payment of the compensation should have been granted within 21 days. Based on the amendment, however, there was the extension of the above mentioned obligation until 31. 12. 2013. Until 2009 in Estonia, the law of 1992 on employment contracts did not establish an obligation to contribute to the compensation during the sick leave. Then, there was a substantial change, and nowadays employers must pay $70 \%$ of the previous income from the 4 th to the 8 th day of the incapacity for work (European Commission, 2010).

Moreover, Ireland has decided since 2012 on the taxation of sickness insurance from the first week of receiving the compensation. Till then, the compensation was subject to tax only after six weeks.

The second hypothesis related to the maternity benefit and no changes were expected in the light of the demographic trend. Thus the hypothesis was confirmed just partially. The cut in the benefit took place in Latvia, from $100 \%$ to $80 \%$. Moreover in the years 2010 to 2014 , it pays that a part of the maternity benefit exceeding the limit is cut to half the amount. In Ireland, in 2010 and 2011, the maternity benefits were decreased by a minimum and maximum limit (for example the maximum was reduced from Euro 280 per week in 2009 to Euro 270 in 2010 and down to 262 Euro in 2011). However, the principle that the benefit is calculated as $80 \%$ fixed income (while maintaining limits) was maintained, but should it happen that there was an increase in the sickness benefit due to the dependents in the family, this more favourable amount is admissible. Additionally, it was decided, from July 2013 , to tax the maternity benefit.

In 2010 the Czech Republic introduced a temporary reduction in maternity benefit from $70 \%$ of the daily assessment base to $60 \%$. Moreover, a more stringent calculation of the assessment base was adopted. Due to a considerable disagreement of both the professionals and the public the amendment of the law brought back the initial method of calculation applied before 2010 and there was introduced a recovery of the supplement of the maternity benefit for the period from 1.1.2010 until the effective date of the relevant amendment, i. e. 31st May, 2010. The Slovak Republic adopted a gradual increase of the benefit from $55 \%$ to $60 \%$ in 2011 and 65\% in 2012.

In the case of the support period for maternity benefit some changes were adopted, however of contradictory nature. Slovakia prolonged, among other things, a base length of the eligibility for support from 28 weeks up to 34 and in the case of multiple births from 37 to 43 weeks. Estonia conversely cancelled a prolonged payment due to multiple births or a complicated childbirth from 154 days to down to 140 days, in general.

Regarding the position of employers, the obligation to continue payment of wages / salary during the maternity leave is anchored in the law of several states. Newly such an obligation has been introduced in Greece, where the employer continues paying the salary for 15 days in the first year of the employment contract, if the woman worked at least 10 days. If the employment contract lasted more than one year, the employer can pay a wage for one additional month. Wages can be reduced by an amount corresponding the benefit that the woman receives from social institutions (European Commission, 2010). 
The third hypothesis, according to which no changes were expected in nursing benefit regarding the fact that the support period for this benefit is typically much shorter and the impact of austerity measures would be marginal, was confirmed. The amount of the nursing or sickness benefit provided remained the same in all examined countries. In 2010 in the Czech Republic there was, in case of the nursing, temporarily introduced a waiting period of 3 days. But that measure was met with great disapproval of the public and the amendment to the adjustment was withdrawn the same year. In Estonia, there was a reduction of the sickness benefit, but nursing remained unchanged. In the same period, a nursing benefit was introduced in Spain (European Commission, 2011).

\section{Conclusions}

It can be concluded that the austerity measures adopted in the studied countries primarily as a response to the financial crisis, touched both the field of social security as well as cash benefits for sickness and maternity. At the same time, major changes have taken place or are underway in Ireland and in the countries of Central and Eastern Europe. They focus mainly on a sick leave. In contrast, Germany, Austria, Finland and Sweden did not adopt fundamental changes in terms of benefits. And surprisingly neither Greece nor Spain materialised any significant savings (actually non in case of Greece). In the year 2011 came in Sweden into effect new Social Insurance Code, which brought along a partial change compared to the previously existing legislation, but not in the direction of austerity measures in the monitored area.

Ireland decided to reduce sickness benefit and to tax it already from the first week of receiving. As for maternity benefit minimum and maximum levels of the benefit were reduced and newly it is also a subject to taxation. The development in the Slovak Republic has brought savings in the form of a substantial shortening of the withdrawal period, but in terms of the maternity benefit there was an extension of the payment of the benefit as well as to its gradual increase. Recently, a nursing benefit was introduced in Spain.

For sake of completeness we shall note that namely those states which remained untouched by austerity measures and which set for maternity, sickness or nursing benefits minimum or maximum assessment bases for their calculation or other similar limitations maintained their standard rate or conducted a regular valorisation (for example Finland).

The above-mentioned findings correspond with the fact that majority of the surveyed countries has undergone in recent years through stagnation or even an economic decline. But it cannot be proved that there is a direct link between the dynamics of the economic growth (decline) and a change in social security spending, including cash benefits for sickness and maternity. Rather, different patterns of economic and social policies were reflected themselves, and of course the political preferences of individual countries. In countries with more liberal social models one can record more aggressive interventions. In the states of South Europe, on the contrary, a fiscal multiplier is pretty much employed, thus reducing expenditures is linked not only with social but also with negative economic effects (measures mitigate the economic growth). That is also why any interventions in public finances are more considered. In terms of demographic factors studied they proved no correlation with the examined types of illness expenditures. On the contrary, the vast maintaining of the current level of maternity pays or even prolonging their receipt in the examined period in most countries has its real demographic causes.

\section{References}

[1] BUREŠ, J. Ekonomické souvislosti dosavadniho managementu euro-krize. Acta Universitatis Carolinae - IURIDICA 1/2012. Praha: Univerzita Karlova.

[2] EUROPEAN COMMISSION (2013). General Government Data - Spring 2013. Luxembourg: The Publications Office of the European Union, s. 5.

[2] LABOUTKOVÁ, Š. , KOCOUREK, A. , BEDNÁŘOVÁ, P. On the Relationship between Globalization and Human Development. In Proceedings of the 10th International Conference Liberec Economic Forum 2011. 1. vyd. Liberec: Technická univerzita v Liberci, 2011. S. 61 - 71. ISBN 978-80-7372-755-0. 
[3] UŠIAK, J. 2011 European Political Culture and European Community. In Identités, citoyennetés et démocratie : 20 ans aprés = Identities, citizenship and democracy : 20 years after. Bruxelles: BRUYLANT, 2011. ISBN 978-2-8027-3085-9, s. 109-121

[4] EUROPEAN COMMISSION. MISSOC - Social protection in the Member States of the European Union, of the European Economic Area and in Switzerland - Situation on 1 January 2009. Luxembourg: Office for Publications of the European Communities, 2009.

[5] ČAJKA, P. : Problematika regionálnej politiky. In: Politické vedy 3/2001, Ročník IV. , Banská Bystrica: FPV a MV UMB, 2001, s. 51-104, ISSN 1335-2741

[6] HUSENICOVÁ, L. Reflexia liberálnej teórie medzinárodných vzt'ahov v bezpečnostných štúdiách. In Bezpečnostné fórum 2013 = Security forum 2013. Sborník vědeckých praci / volume of scientific papers / Banská Bystrica: Univerzita Mateja Bela, Fakulta politických vied a medzinárodných vzt'ahov, 2013. ISBN 978-80-557-0496-8, s. 280-287.

[7] HOSŤOVECKÝ, M. , MIŠUT, M. , PRIBILOVÁ, Web based testing in science education. In Lecture Notes in Electrical Engineering In Innovations and Advances in Computing, Informatics, Systems Sciences, Networking and Engineering, 2015, Springer International Publishing, ISBN 978-3-319-06772-8, pp. 247-254.

[8] EUROPEAN COMMISSION. MISSOC - Social protection in the Member States of the European Union, of the European Economic Area and in Switzerland - Situation on 1 January 2013. Luxembourg: Office for Publications of the European Communities, 2014.

[9] RUBÁČEK, F. Porovnáni prǐstupnosti webových prezentaci středních škol v České a Slovenské republice. In Technológia vzdelávania. 2011. ISSN 1338-1202.

[10] EUROPEAN COMMISSION. MISSOC - Social protection in the Member States of the European Union, of the European Economic Area and in Switzerland - Situation on 1 January 2013. Luxembourg: Office for Publications of the European Communities, 2011.

[11] EUROPEAN COMMISSION. MISSOC - Social protection in the Member States of the European Union, of the European Economic Area and in Switzerland - Situation on 1 January 2013. Luxembourg: Office for Publications of the European Communities, 2013.

[13] RIMŠEVIČS, I. Lessons from Latvias internal adjustment's. Bank of Latvia. 2012.

[14] BUREŠ, J. , CHARVÁT, J. , JUST, P. , ŠTEFEK, M. Česká demokracie po roce 1989. Institucionální základy českého politického systému. Grada, Praha, 2012, 526 stran ISBN 978-80-247-4283-0

[15] ESPING-ANDERSEN, G. The Three Worlds of Welfare Capitalism. Princeton: Princeton University Press. 1990. ISBN 978-0691094571.

[16] EVROPSKÁ CENTRÁLNÍ BANKA (2010). Konvergenční zpráva: květen 2010. ECB. Frankfurt nad Mohanem.

[17] MUDRYCH, K. , MUDRYCHOVÁ. J. Maturitni otázky - ekologie. Brno: Radek Veselý. 1. vydání. 1999. 136 s. ISBN10: 80-902473-8-2. 